\title{
A Fifteen Level Inverter Topology for Grid Connected Applications
}

\author{
Kalagotla.Chenchireddy, V. Jegathesan, L. Ashok Kumar
}

\begin{abstract}
This paper proposes a single-phase fifteen-level inverter using seven switches, with a novel pulse width-modulated control method. The Proposed multilevel inverter output voltage level rising by using less number of switches driven by the multicarrier modulation techniques. The inverter is capable of producing fifteen levels of output-voltage from the dc supply voltage. The proposed system was verified through simulation and implemented in a prototype.
\end{abstract}

Key words: Multilevel Inverter, Harmonics, Switching Loss.

\section{INTRODUCTION}

Electrical power generation, transmission and distribution major role in developing country. But conventional energy sources, decreasing fossil fuels, coal and firewood. The importance of renewable energy sources, increasing day to day life. Renewable energy sources like solar, wind, tidal, biomass. All these sources, solar and wind advanced power electronics. We need a suitable converter for converting DC to AC in solar. These papers design fifteen level inverters.

Multilevel inverter designed [1] with minimization of switching frequency. Space vector modulation technique most effective technique for minimization switching frequency and increasing reliability, efficiency, decreasing complexity. Reduced Common mode voltage, switching loss and in harmonic distortion. Multilevel inverter [2] used space vector modulation technique.

Common mode voltage, high switching loss, modulation depth and high harmonic distortion common problems in multilevel inverter. These problems reduced using space vector modulation scheme in cascaded multilevel inverter. Finally improved overall performance in MLI [3]. Reduced zero-order voltage and find out shortest switching path for multilevel inverter. In this paper, a novel multilevel inverter has been proposed using a reduced amount of number of switching for 15 levels. These multilevel inverters only seven switches and three DC sources.

\section{PROPOSED TOPOLOGY}

The main objective of this topology is to improve the quality output voltage of the multilevel inverter. An important issue MLI designed is that to produce almost

Revised Version Manuscript Received on 16 September, 2019.

Kalagotla.Chenchireddy, Research scholar, Dept of EEE, Karunya Institute of Technology and Sciences, Coimbatore, T.N, India.

(Email: chenchireddy.kalagotla@gmail.com)

Dr V. Jegathesan, Associate Professor Dept of EEE, Karunya Institute of Technology and Sciences, Coimbatore, T.N, India.

(Email: jegathesan@karunya.edu)

Dr L. Ashok Kumar, Professor Department of EEE, PSG College of technology, Coimbatore, T.N, India.

(Email: askipsg@gmail.com) sinusoidal output voltage waveform and to eliminate lower order harmonics.

\section{A. Fifteen Level Multilevel Inverter}

A fifteen level proposed inverter uses only seven switches compared to cascaded H-bridge multilevel inverter which uses 16 switches and three separate dc sources. Fifteen levels Cascaded H-bridge [4] voltage source inverter designed and eliminated harmonics in MLI. But cascaded type inverter used 12 switches. The proposed inverter less switches compare to other inverters like diode clamped multilevel inverter, flying capacitor multilevel inverter, cascaded multilevel inverter. Diode clamped MLI used more diodes and more switches single voltage source. Flying capacitor multilevel inverter capacitors balancing difficult.

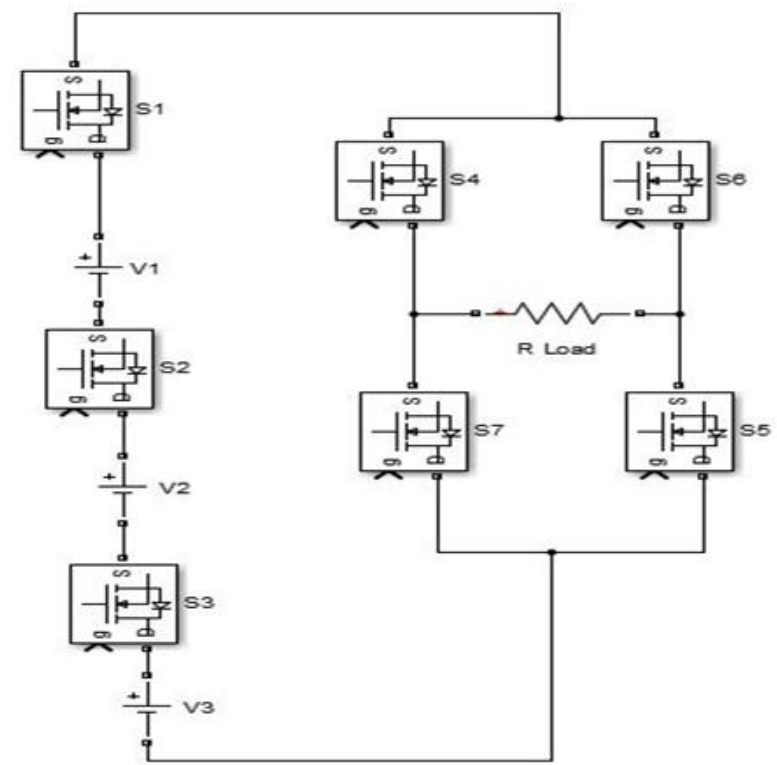

Fig.1 proposed power circuit for 15-level output.

Circuit diagram of proposed fifteen level multilevel inverter is shown in fig.1. for generating 15 level, the proposed inverter uses three cells that mean it contains three swatches and three diodes in adding with the one H-bridge. Table I shows the switching sequence used for creating fifteen levels for output voltages. 
Table I: Switching Pattern for Fifteen Level Inverter

\begin{tabular}{|l|l|l|l|l|l|l|l|l|}
\hline Level & SW1 & SW2 & SW3 & SW4 & SW5 & SW6 & SW7 & $\begin{array}{l}\text { Output } \\
\text { voltage }\end{array}$ \\
\hline 1 & 1 & 1 & 1 & 0 & 0 & 1 & 1 & $84 \mathrm{~V}$ \\
\hline 2 & 0 & 1 & 1 & 0 & 0 & 1 & 1 & $72 \mathrm{~V}$ \\
\hline 3 & 1 & 0 & 1 & 0 & 0 & 1 & 1 & $60 \mathrm{~V}$ \\
\hline 4 & 0 & 0 & 1 & 0 & 0 & 1 & 1 & $48 \mathrm{~V}$ \\
\hline 5 & 1 & 1 & 0 & 0 & 0 & 1 & 1 & $36 \mathrm{~V}$ \\
\hline 6 & 0 & 1 & 0 & 0 & 0 & 1 & 1 & $24 \mathrm{~V}$ \\
\hline 7 & 1 & 0 & 0 & 0 & 0 & 1 & 1 & $12 \mathrm{~V}$ \\
\hline 8 & 0 & 0 & 0 & 1 & 0 & 0 & 0 & 0 \\
\hline 9 & 1 & 0 & 0 & 1 & 1 & 0 & 0 & $-12 \mathrm{~V}$ \\
\hline 10 & 0 & 1 & 0 & 1 & 1 & 0 & 0 & $-24 \mathrm{~V}$ \\
\hline 11 & 1 & 1 & 0 & 1 & 1 & 0 & 0 & $-36 \mathrm{~V}$ \\
\hline 12 & 0 & 0 & 1 & 1 & 1 & 0 & 0 & $-48 \mathrm{~V}$ \\
\hline 13 & 1 & 0 & 1 & 1 & 1 & 0 & 0 & $-60 \mathrm{~V}$ \\
\hline 14 & 0 & 1 & 1 & 1 & 1 & 0 & 0 & $-72 \mathrm{~V}$ \\
\hline 15 & 1 & 1 & 1 & 1 & 1 & 0 & 0 & $-84 \mathrm{~V}$ \\
\hline
\end{tabular}

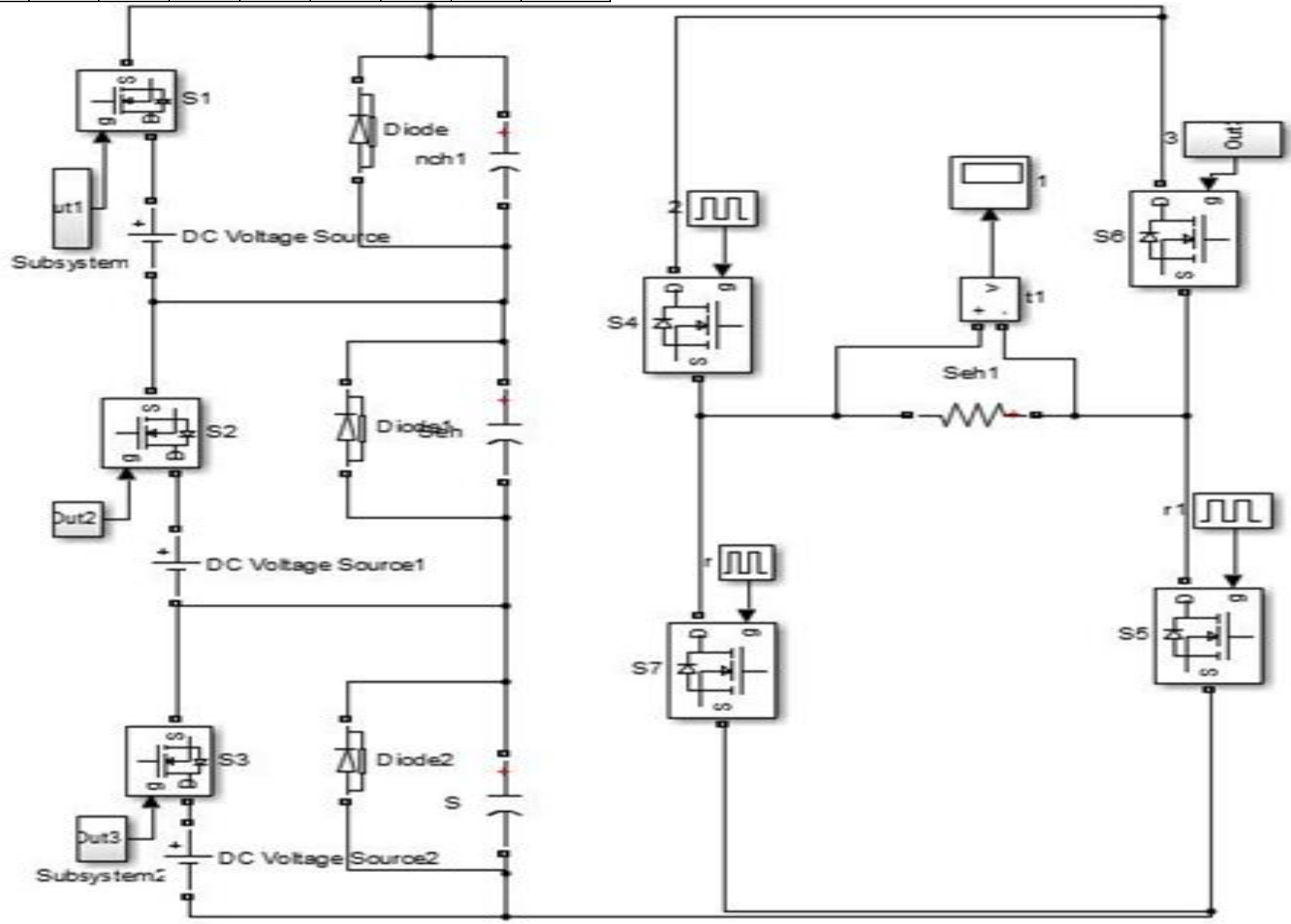

Fig. 2 Fifteen level inverter topology

TABLE 2: Simulation parameters of fifteen level inverter system

\begin{tabular}{|l|l|}
\hline parameter & Value \\
\hline DC voltage source(V) & $\mathrm{V}=12, \mathrm{~V} 1=24, \mathrm{~V} 2=48$ \\
\hline Capacitor's (nF) & 100 \\
\hline R-load (ohm's) & 100 \\
\hline Output voltage (peak to paek) & $74 \mathrm{~V}$ \\
\hline Utility frequency (HZ) & 50 \\
\hline Inductance H & 100 \\
\hline
\end{tabular}

\section{SIMULATION RESULTS}

The proposed fifteen level inverter is simulated using Matla/ Simulink. The simulation is made in open loop. Here the input voltage can be selected as $12 \mathrm{~V}, 24 \mathrm{VBand} 48 \mathrm{~V}$ to get an output voltage as $84 \mathrm{~V}$. The Matlab / Simulink model is as shown fig. 2 the three unlike input voltages as given $12 \mathrm{~V}$, $24 \mathrm{~V}$ and $48 \mathrm{~V}$. These voltages are given to 7 different switches which are associated proposed 15 levels MLI. 


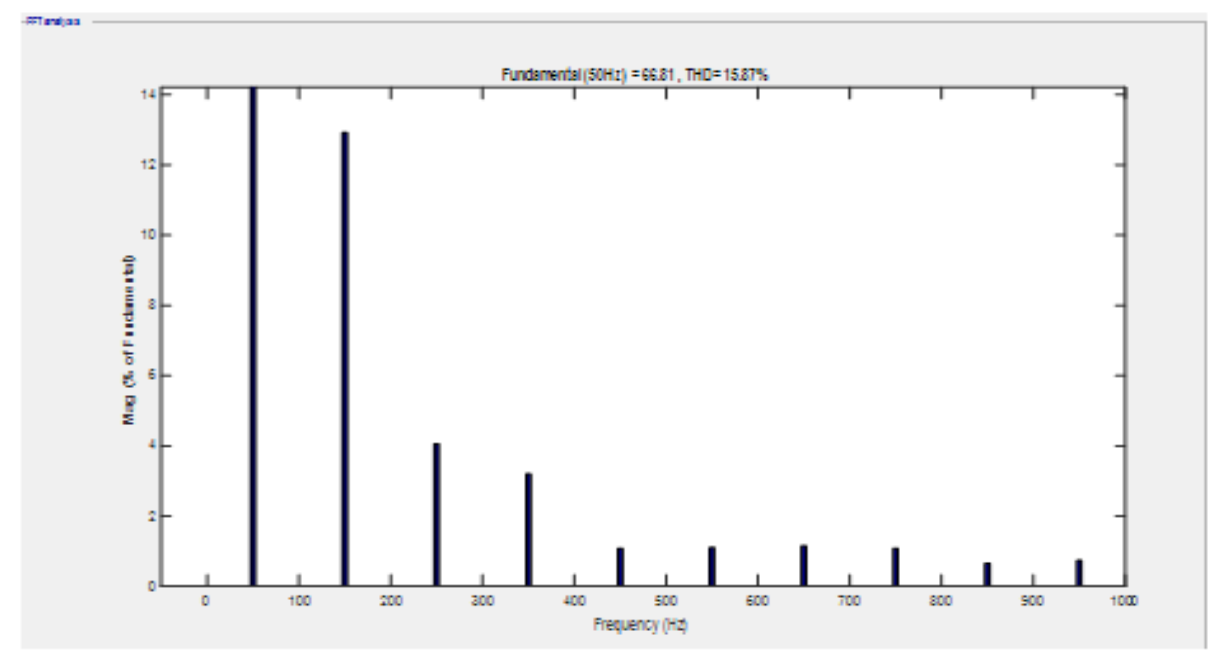

Fig.4 harmonic spectrum for fifteen level R-load output voltage

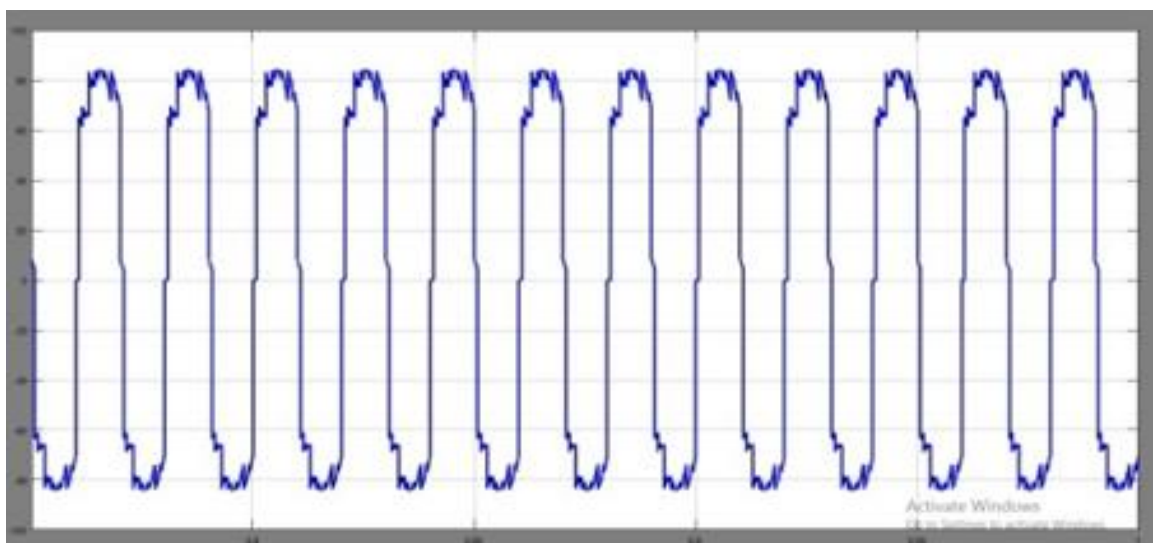

Fig.5 Simulation result for fifteen level multilevel inverter with L-Load

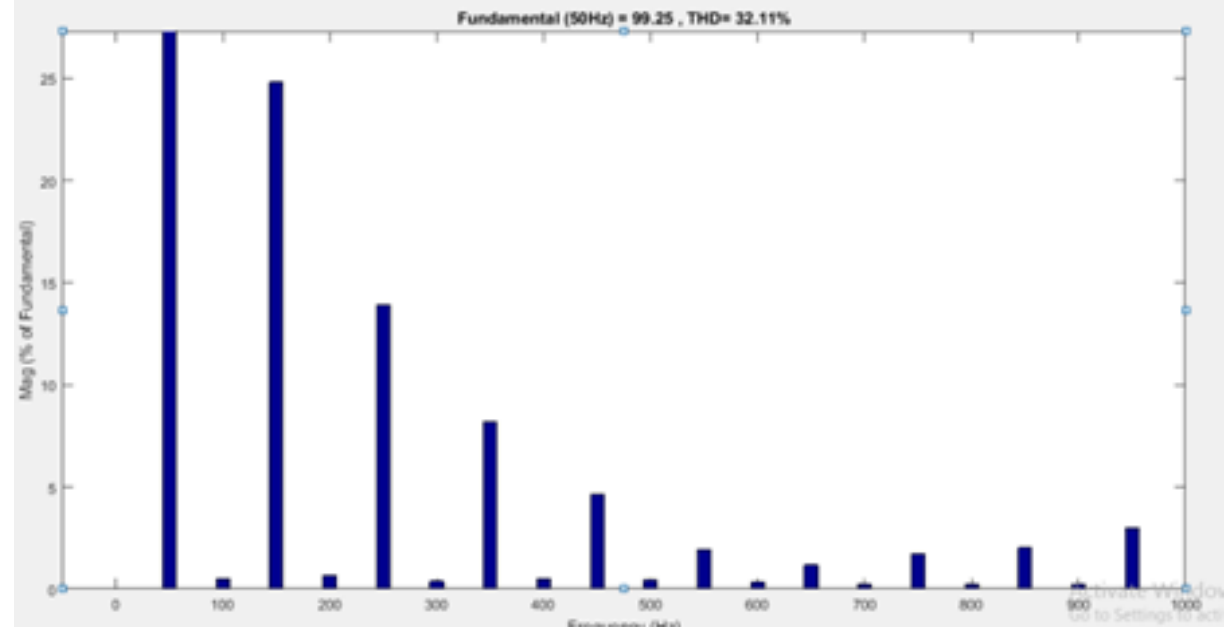

Fig.6 harmonic spectrum for fifteen levels L-load output voltage 


\section{THE EXPERIMENTAL RESULTS}

The proposed 15 level inverter hardware components. Three DC sources with reduce number of switches. Three input sources given from solar panel. Boost converter used for increasing voltage. Multilevel inverter circuit reduced seven switches. PIC-microcontroller used for generating pulses for multilevel inverter.

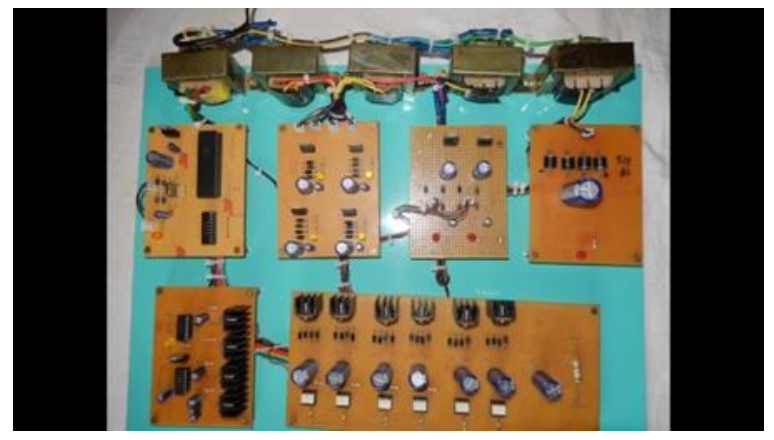

Fig 7. Experimental Setup Of 15- Level Inverter

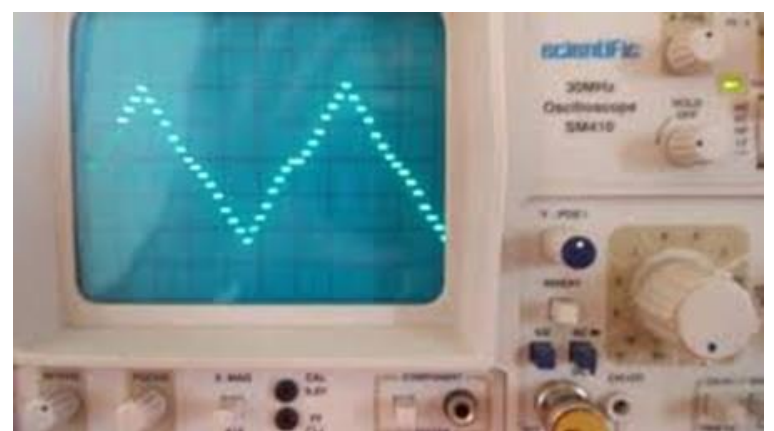

Fig 8. Output Voltage Waveform

\section{CONCLUSION}

Multi-Level electrical converter is that the most typically used. It acting a lot of and a lot of vital role in several industrial applications. during this paper a NOVAL FIFTEEN LEVEL electrical converter is introduced. associate terribly giant output voltage is obtained with the planned convertor and also the voltage stress on the ability devices is reduced. what is more it needs seven MOSFETs. fifteen levels acquire with less harmonic distortion.

\section{REFERENCES}

1. Yong - Chao Liu, Xinglai Ge, Qidi Tang and Bin Gou "two changed SVPWM algorithms for common-mode voltage reduction in eight-switch three-phase inviters" physical science letter eleventh might 2017 Vol.53 N0.10 pp.676-678.

2. Ifran Ahmed, Vijay B.Borghate, Amarendra Matsa, M. Meshram, H.M.Suryawanshi " simplified area vector modulation techniques for construction inverters" IEEE 2015.

3. Amit Kumar Gupta, Ashwin M.Khambadkone "a area vector modulation theme to cut back common mode voltage for cascaded construction inverters" IEEE 2017.

4. Zainal Salam, Ahmed Majed, Abdul Moeed Amjad "Design and implementation of 15-level cascaded multi-level voltage supply electrical converter with harmonics elimination pulse-width modulation exploitation differential evolution method" IET Power physical science eighteenth Gregorian calendar month 2015. 